\title{
Effects of Immature Coconut Water on the Hepato- Cytoarchitecture Against Carbontetrachloride-induced Liver Damagein Wistar Rats
}

\author{
Wilson Chimaobi Okafor ${ }^{1}$, Gideon Ihebuzo Ndubuka ${ }^{2}$, Ekezie Jervas ${ }^{3}$, Iwuji \\ Samuel Chidi ${ }^{4}$, Okeke Chukwubuike Udoka ${ }^{5}$, Osuchukwu Ikechukwu, William ${ }^{6}$ \\ ${ }^{1,2,4}$ Department of Biomedical Technology, Federal University of Technology, Owerri, Nigeria. \\ ${ }^{3}$ Department of Anatomy, Federal University of Technology, Owerri, Nigeria. \\ ${ }^{5,6}$ Department of Prosthetics and Orthotics, Federal University of Technology, Owerri, Nigeria.
}

\begin{abstract}
The peculiar features of immature coconut water (ICW) have made it a therapeutic agent that can be used extensively in the field of medicine for both preventive, management and curative purposes. Development of a more efficient and cost effective means of prevention and management of liver disorders through antioxidant activities were the objectives for embarking on the current experiment. This experiment is aimed at investigating the protective effect of ICW against carbon tetrachloride $\left(\mathrm{CCl}_{4}\right)$ induced hepatotoxicity. 20 rats were fed on standard diet and divided into four groups. Rats in group 1 and group 2 were injected intraperitoneally (i.p) with olive oil. Group 1 received tap water only, while group 2 received ICW $(100 \mathrm{ml} / \mathrm{kg}$ body weight/day) only. Rats in Group 3 and Group 4 were injected i.p with $\mathrm{CCl}_{4}(5 \mathrm{ml} / \mathrm{kg}$ body weight). Group 3 received tap water, while group 4 received ICW $(100 \mathrm{ml} / \mathrm{kg}$ body weight/day) only. At the end of the experiment (1 week), liver samples were collected for histopathological analysis. The present findings revealed that a significant cyto-architectural distortion, hepatocyte degeneration, necrotic cells, fatty liver, and inflammatory cell migration were observed in the liver of $\mathrm{CCl}_{4}$ treated group when compared with the normal control, positive control, and the experimental groups. The present study concluded that ICW administration played a protective role against $\mathrm{CCl}_{4}$-induced liver damages in Wister rats. These protective effects were in the form of retaining the histological features of liver in the experimental group.
\end{abstract}

Keywords: Protection, Hepatocyte, Immature coconut water, Histopathology.

\section{Introduction}

The high regenerative ability of the liver does not prohibit damage from occurring as a result of drugs and toxins or viral infection. These agents can cause extensive damage to hepatocyte, reducing function and regeneration, and thereby leading to liver failure. Usually, death occurs as a result of multi-organ failure [1-4]. Thus, liver diseases remain one of the more serious health problems $[5,6]$.

Carbon tetrachloride $\mathrm{CCl}_{4}$ is widely used for experimental induction of liver damage [7-9].Toxicity of $\mathrm{CCl}_{4}$ is a well characterized murine model for the study of oxidative damage in vivo [10]. It results from its reductive dehalogenation by the liver cytochrome P450 enzyme system into the trichloromethyl free radical, which readily interacts with molecular oxygen to form trichloromethylperoxyl radicals [10-12]. These radicals are hepatotoxic [11, 12]. Hepatotoxicity of $\mathrm{CCl}_{4}$ is of lipid peroxidation origin [13, 14], which can lead to cell injury and liver damage, in a similar way as what happens in the cases of acute hepatitis $[15,16]$.

In this sense, antioxidant action and growth stimulators play an important role in protecting the liver against $\mathrm{CCl}_{4}$-induced liver injury. The protective effects of various natural and synthetic products against hepatotoxicity have been reported $[17,19]$, with varying degrees of protection.

Immature coconut water (ICW) is the liquid found inside green coconut before the coconut matures and turns acidic [20]. It contains the various vitamin B complexes [21], vitamin C $(15 \mathrm{mg} / 100 \mathrm{~mL})$, and a free amino acid L-arginine $(30 \mathrm{mg} / \mathrm{dL})$, that significantly reduce lipid peroxidation when introduced in rats [22]. Besides, young coconut water contain sugars, sugar alcohols, phytohormones (auxin, 1, 3-diphenylurea, cytokinin), enzymes (acid phosphatase, catalase, dehydrogenase, diastase, peroxidase, RNA polymerases) and growth promoting factors [23]; and it is also highly rich in Inorganic ions such as $\mathrm{K}(290 \mathrm{mg} \%), \mathrm{Na}$ (42 $\mathrm{mg} \%), \mathrm{Mg}(10$ $\mathrm{mg} \%), \mathrm{P}(9.2 \mathrm{mg} \%)$ etc. The concentration of these electrolytes in ICW generates an osmotic pressure similar to that observed in blood [24] and does not affect plasma coagulation. Micronutrients act directly to quench free radicals by donating electrons, or indirectly as a part of metallo enzymes [25].

In this present study, we investigated the protective effects of immature coconut juice against $\mathrm{CCl}_{4^{-}}$ induced liver toxicity in rats by examining the hepatic cyto-architecture. 


\section{Plant Materials}

\section{Materials and Methods}

Young coconuts were (Cocosnucifera L.) collected from Eziobodo Community, in Owerri-West Local Government Area of Imo State, Nigeria. It was authenticated and identified by the department of Forestry \& Wildlife, School of Agricultural Technology, Federal University of Technology, Owerri; as a dwarf (autogamous) Coconut (Cocosnucifera L. Arecaceae). The fresh ICW was obtained from the coconuts each time it is required for administration on the Wister rats.

\section{Experimental Animals}

A total of 20 adult male Wistar rats with body weights of 175-200g obtained from Animal House of the Department of Forestry \& Wildlife, School of Agricultural Technology, Federal University of Technology, Owerri, Nigeria were used in the study. The experimental animals were housed in air-conditioned rooms at 23$25^{\circ} \mathrm{C}$, kept on a $12 \mathrm{~h} / 12 \mathrm{~h}$ light/dark cycle and had free access to standard rodent pellet diet and water ad libitum. The animals were acclimatized in the laboratory conditions for a week before the commencement of the study. The experimental procedures adopted in this study were in strict compliance with the United States National Institutes of Health Guidelines for Care and Use of Laboratory Animals in Biomedical Research (1985, no. 85-23).

\section{Chemical}

Carbon tetrachloride (Riedel-de Haen AG Seelze-Hannover), Olive oil and other chemicals and solvents were of highest grade commercially available.

\section{Induction of Renal Toxicity $\mathrm{By} \mathrm{Ccl}_{4}$}

Liver toxicity was induced by the intraperitoneal injection of Carbon tetrachkoride $\mathrm{CCl}_{4}$, diluted with distilled water and vector (Olive oil) in the ratio of 1:2:0.5 respectfully. Dosage was determined using $5 \mathrm{ml} / \mathrm{kg}$ body weight, as a standard. Therefore, the specific dosage for each Wister rat was calculated thus:

Milligram Equivalent for toxicity induction $=\frac{5 \mathrm{ml} \times \text { weight } \text { of rats }(\mathrm{g})}{1000 \mathrm{~g}}$

\section{Determination of Dosage for the Administration of Immature Coconut Water (ICW) in Experimental Animals.}

Immature coconut water (ICW) was administered through intragastric injection. The dosage was determined using $100 \mathrm{ml} / \mathrm{kg}$ body weight, as a standard. Therefore the specific dosage for each Wister rat was calculated thus:

\section{Milligram Equivalent for ICW Administration $=\frac{100 \mathrm{ml} \times \text { weightofrat }(g)}{1000 \mathrm{~g}}$}

\section{Experimental Group And Protocol}

The rats were divided randomly into 4 groups comprising 5 rats in each group. They were all fed with the same diet throughout the experimental period. The experimental design is described as follows:

\begin{tabular}{|l|l|}
\hline Group & Protocol \\
\hline Group I & $\begin{array}{l}\text { This group is made up } 5 \text { male rats with weights ranging from 175g-200g. Rats were fed } \\
\text { only with basal diet and tap water. }\end{array}$ \\
\hline Group II & $\begin{array}{l}\text { This group is made up } 5 \text { male rats with weights ranging from } 175 \mathrm{~g}-200 \mathrm{~g} \text {. Rats were fed } \\
\text { normal basal diet, injected i.p with Olive oil and received immature coconut water (ICW) } \\
\text { (100 ml/kg body weight/day) as their sole source of drinking water [the calculated dosage } \\
\text { young coconut juice was given in fragments of 3 times (i.e 8am, 1pm, and 5pm) daily; via } \\
\text { intragastric injection]. This group served as positive control. }\end{array}$ \\
\hline Group III & $\begin{array}{l}\text { This group is made up } 5 \text { male rats with weights ranging from 175g-200g. Rats were fed } \\
\text { basal diet and tap water, and then they were intoxicated via intraperitoneal injection on } \\
\text { the } 7^{\text {th }} \\
\text { ratio of } 1: 2: 0.5 \text { respectively. The dosage given was } 5 \mathrm{ml} / \mathrm{kg} \text { body weight. This group } \\
\text { served as the negative control }\end{array}$ \\
\hline
\end{tabular}




\begin{tabular}{|l|l|}
\hline Group IV & $\begin{array}{l}\text { This group is made up } 5 \text { male rats with weights ranging from } 175 \mathrm{~g}-200 \mathrm{~g} \text {. Rats were fed } \\
\text { basal diet and young coconut juice }(100 \mathrm{ml} / \mathrm{kg} \text { body weight } / \mathrm{day}) \text { as their sole source of } \\
\text { drinking water [the calculated dosage of } \mathrm{ICW} \text { was given in fragments of } 3 \text { times (i.e } 8 \mathrm{am}, \\
1 \mathrm{pm} \text {, and } 5 \mathrm{pm}) \text { daily; via intragastric injection], and then they were intoxicated via } \\
\text { intraperitoneal injection on the } 7^{\text {th }} \text { day of the experiment with } \mathrm{CCl}_{4} \text { diluted with distilled } \\
\text { water and Olive oil, at a ratio of } 1: 2: 0.5 \text {. The dosage given was } 5 \mathrm{ml} / \mathrm{kg} \text { body weight. This } \\
\text { group served as the negative control. }\end{array}$ \\
\hline
\end{tabular}

\section{Tissue Collection, Processing and Examination}

At the end of the experiment, the overnight fasted animals (the control and experimental animals) were sacrificed and liver tissue samples were collected for histological analysis. The kidney tissues were cut in small pieces and immersed in neutral buffered formalin $10 \%$ and processed for histological studies, using standard methods [27]. The extent of $\mathrm{CCl}_{4}$-induced necrosis was evaluated by assessing the morphological changes in the liver sections stained with hematoxylin and eosin ( $\mathrm{H}$ and $\mathrm{E}$ ). Photomicrographs were taken using digital microscope eyepiece SCOPETEK DCM 500, 5.0 mega pixels.

\section{Results}

Then results obtained are shown in Plate 1-4 below:

\section{Microscopic Examination of the Liver}

Normal Control Group: Photomicrograph of a section of the liver shows a central vein with arrays of binucleated hepatocytes which are uniformly distributed throughout the cytoplasmic matrix. The nuclei appeared rounded and are eccentrically positioned. The sinusoids are intact and no pathological lesion seen. Morphological features are in line with that of a normal liver, as shown in plate 1.

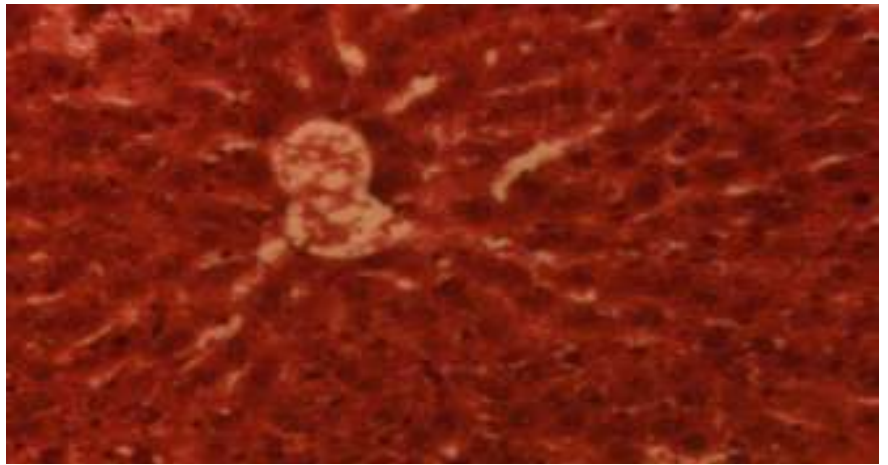

Plate 1: Showing a liver section from the normal control group (H\&E x400).

Positive Control Group: Photomicrograph showing the section of the liver with a dilated portal vein, constricted hepatocytes with prominent nucleoli amidst an eosinophilic background and cell migration. No lesion was observed. The sinusoids remain intact with morphology in line with that of control, as shown in plate 2.

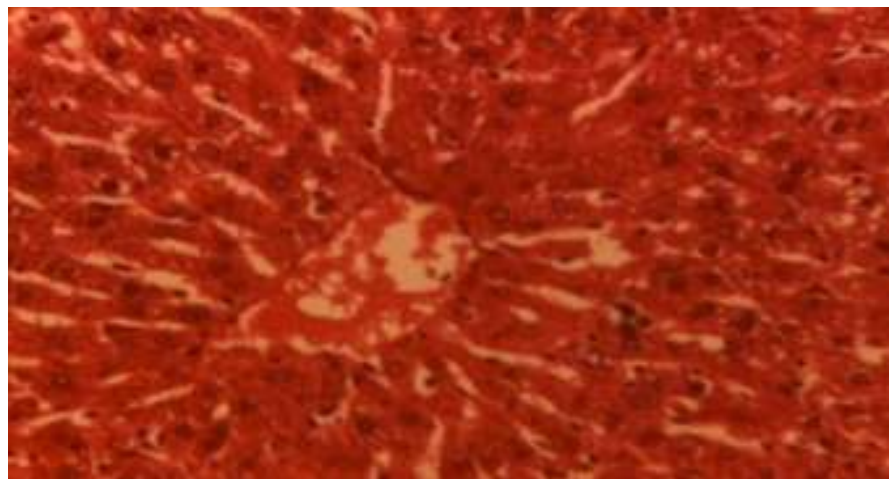

Plate 2: Showing a liver section from the positive control group (H\&E x400) 
Negative Control Group: Photomicrograph of a section of the liver show high degenerative changes in liver cyto-architecture, formation of reticulocytes, fatty cells, mononuclear inflammatory cells, few polymorphs and necrosis, as shown in Plate 3.

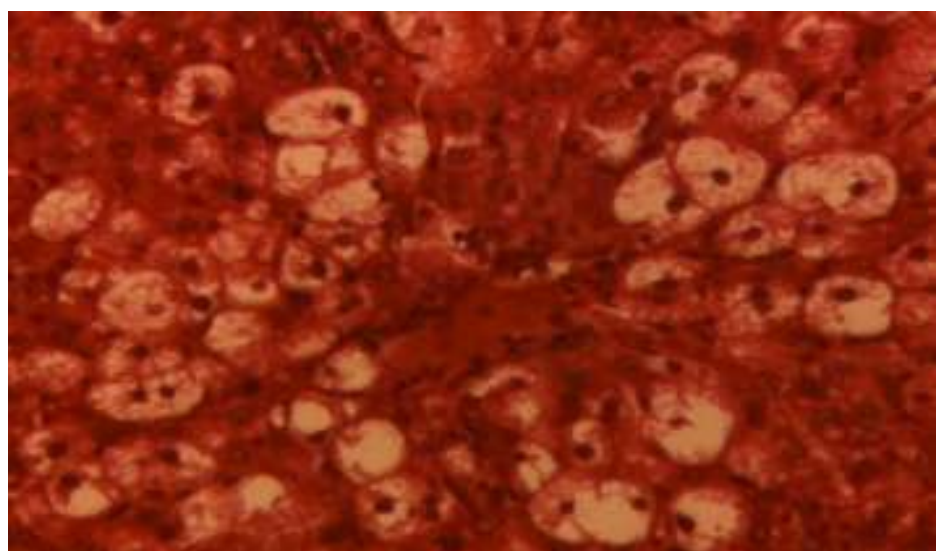

Plate 3: Showing a liver section from the negative control group (H\&E x400)

Experimental Group: Photomicrograph of a section of the liver show hepatocyte degeneration, nuclear fragmentation and moderate necrosis when compared to the negative control; as shown in Plate 4.

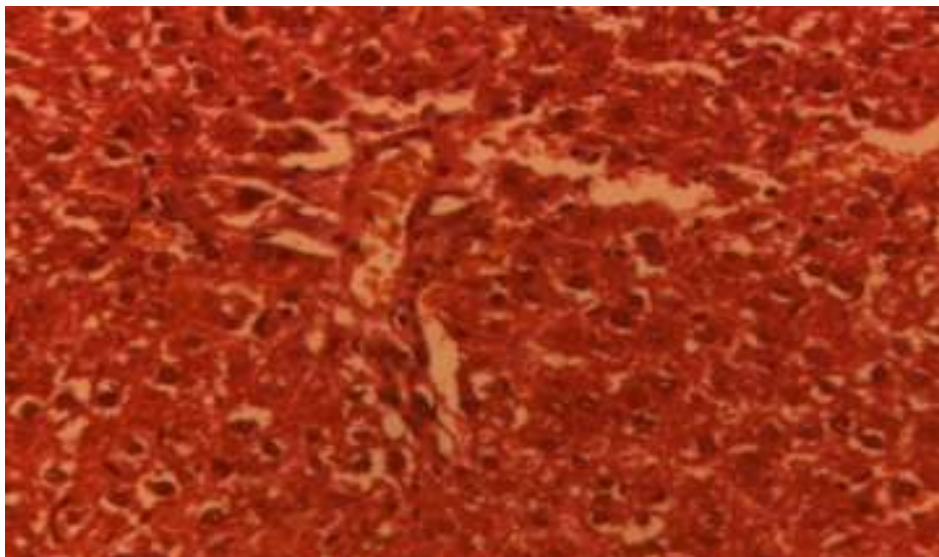

Plate 4: Showing a liver section from the experimental group (H\&E x400).

\section{Discussion}

Carbon tetrachloride-induced toxicity is a well characterized murine model for the study of oxidative damage in vivo [10], as it has been found that metabolism of $\mathrm{CCl}_{4}$ involves the production of free radicals. Hence, the effort towards the prevention of hepatic damage by eliminating free radicals and prevent lipid peroxidation, is justified.

In this present study, the cyto-architectural features of the liver as shown in plate 1, presents a centrally placed portal vein with arrays of bi-nucleated hepatocytes which are uniformly distributed throughout the cytoplasmic matrix. The nuclei appeared rounded and are eccentrically positioned. The sinusoids are intact and no pathological lesion seen. Thus depicting the absence of free radicals which would have resulted in cell injury, histopathological lesions or hepatic damage [28-32]. In plate 2, the hepatic cyto-architecture shows that the sinusoids are intact, in line with that of the normal control in plate 2. However, the presence of prominent nucleoli amidst an eosinophilic background and cell migration depicts an inflammatory response as a result of the immature coconut water (ICW). These immunostimulatory effects of ICW have been reported by $[33,34]$

The high degenerative changes in the liver cyto-architecture as observed in the negative control group shown in plate 3 , are as a result of peroxidation of membrane poly unsaturated fatty acids, cell necrosis and giant cells, initiated by free radicals [trichloromethyl $\left(\mathrm{CCl}_{3}\right)$ and oxygen-centered lipid radicals (LO or LOO)[35]. The hepatic damage induced by CCl4 is due to loss antioxidant activity [36-39].

However in the experimental group of this study (plate 4), there were moderate degenerations of hepatocytes, nuclear fragmentation and moderate necrosis when compared to the negative control (plate 3). The attenuation of the $\mathrm{CCl}_{4}$-induced liver damage by ICW showed its free radical scavenging and membrane stabilizing activities [22, 40, 41]. Histopathological assessment of plate 4 shows the ability of ICW to reduce 
the harmful effects of free radicals on the hepatocytes. This therefore, gives a clear pointer that the hepatic physiology was also retained.

\section{Conclusion}

In this present study, the hepatoxicity induced by $\mathrm{CCl}_{4}$ is significantly attenuated by the prior administration of immature coconut water (ICW).

\section{Recommendation}

There is need for an in vitro and an in vivo investigation into the curative and regenerative effect of ICW on hepatocytes.

\section{References}

[1]. Lindroos PM, Zarnegar R, Michalopoulos GK. Hepatocyte growth factor (hepatopoietin A) rapidly increases in plasma before DNA synthesis and liver regeneration stimulated by partial hepatectomy and carbon tetrachloride administration, Hepatology. 1991;13:743-50.

[2]. Michalopoulos GK, DeFrances MC. Liver regeneration.Science. 1997; 276:60-6.

[3]. Mandayam S, Jamal MM, Morgan TR. Epidemiology of alcoholic liver disease. Semin Liver Dis 2004; 24: $217-32$.

[4]. Larson AM, Polson J, Fontana RJ, et al. Acetaminophen-induced acute liver failure: results of a United States multicenter,prospective study. Hepatology .2005; 42: 1364-72.

[5]. Rubinstein D. Epinephrine release and liver glycogen levels after carbon tetrachloride administration. Am J Physiol.1962;203: 1033-1037.

[6]. Suja SR, Latha PG,Pushpangadan P, Rajasekharan S. Aphrodisiac property of Helminthostachyszeylanicain mice. J Trop MedPlants.2002; 3:191-195.

[7]. Parola, M, Leonarduzz, G, Biasi, F, Albono, M, Biocca, G, Polic, Dianzani, MU. Vitamin E dietary Supplementation. Protects against CCl4 induced chronic liver damage and cirrhosis. Hepatology. 1992; 16:1014-1021.

[8]. Ulicna O, Greksak M, Vancova O, Zlatos L, Galbavy S, Bozek P, Nakamo M. Hepatoprotective effect of Rooibos Tea (Aspalathuslinearig) on $\mathrm{CCl}_{4}$-induced liver damage in rats. Physiol. Res. 2003; 52:461-466.

[9]. Yan-Jun, L, Jie ping, Y, Zhao-Hong J, Wang L.GingkgoBiloba extracts reverses $\mathrm{CCl}_{4}$-induced liver fibrosis in rats. World J. of Gastroenterology. 2004; 10:1037-1042.

[10]. Williams AT, Burk RF. Carbon tetrachloride hepatotoxicity: an example of three radical-mediated injury. Semin Liver Dis. 1990; 10:279-284.

[11]. Agutter PS, McArdle HJ, McCaldin B. Evidence for involvement of nuclear envelope nucleoside triphosphatase in nucleocytoplasmic translocation of ribonucleoprotein. Nature. 1976; 263: 165-167.

[12]. Li JX, Pang YZ, Tang CS, Li ZQ. Protective effect of taurine on hypochlorous acid toxicity to nuclear nucleoside triphosphatase in isolated nuclei from rat liver. World J Gastroenterol 2004; 10: 694-698.

[13]. Forni LG, Packer JE, Slater TF et al. Reaction of the trichloromethyl radical and halothane derived peroxy radical with unsaturated fatty acids: a pulse radiolysis study. Chem Boil Interact 1983; 85:171-177.

[14]. Park WH, Lee SK, Kim CH. A Korean herbal medicine, panaxnotoginseng, prevents liver fibrosis and hepatic microvascular dysfunction in rats. Life Sci. 2005; 76:1675-1690.

[15]. Novobrantseva TI, Majeau GR, Amatucci A, Kogan S, Brenner I, Casola S, Shlomchik MJ, Koteliansky V, Hochman PS, Ibraghimov A. Attenuated liver fibrosis in the absence of B cells. J Clin Invest.2005; 115: 3072-3082.

[16]. Yoneyama H, Kai Y, Koyama J, Suzuki K, Kawachi H, Narumi S, Ichida T. Neutralization of CXCL10 accelerates liver regeneration in carbon tetrachloride-induced acute liver injury. MedMolMorphol2007; 40: 191-197.

[17]. Halim AB, el-Ahmady O, Hassab-Allah S, Abdel-Galil F, Hafez Y, Darwish A. Biochemical effect of antioxidants on lipids and liver function in experimentally-induced liver damage. Ann ClinBiochem. 1997; 34: 656-63.

[18]. Carbonari KA, Ferreira EA, Rebello JM, Felipe KB, Rossi MH, Felı'cio JD, et al. Free-radical scavenging by Ourateaparviflora in experimentally-induced liver injuries. Redox Rep. 2006; 11:124-30.

[19]. Lin H-M, Tseng H-C, Wang C-J, Lin J-J, Lo C-W, Chou F-P. Hepatoprotective effects of Solanumnigrum Linn extract against CCl4-induced oxidative damage in rats. ChemBiol Interact. 2008; 171: 283-93.

[20]. Alexia Prades, Manuel Dornier, NafissatouDiop, Jean-Pierre Pain., Coconut water uses, composition and properties: a review. Fruits. 2012; 67:87-107. DOI:10. 1051/fruits/20122002.

[21]. United States Department of Agriculture (USDA). National nutrient database for standard reference, Nuts, coconut water, 2008.

[22]. Loki AL, Rajamohan T. Hepatoprotective and antioxidant effect of tender coconut water on $\mathrm{CCl}_{4}$ induced liver injury in rats. Indian J BiochemBiophy. 2003; 40: 354-357.

[23]. Yong WJWH, Ge L, Ng YF, Tan SN. The chemical composition and biological properties of coconut (Cocosnucifera L.). Molecules 2009; 14: 5144-5164.

[24]. Effiong GS, Ebong PE, Eyong EU, Uwah AJ, Ekong UE. Amelioration of chloramphenicol induced toxicity in rats by coconut water. J ApplSc Res. 2010; 6(4): 331-335.

[25]. Shenkin, A. The key role of micronutrients. Clinical Nutr. 2006; 25: 1-13.

[26]. United States National Institutes ofHealth Guidelines for Care and Use of Laboratory Animals in Biomedical Research (1985, no. 85-23).

[27]. Bancroft JD, Gamble M. Theory and Practice of Histological Techniques, 5th edn. Churchill Livingstone, 2002 London, New York and Philadelphia.

[28]. Forni LG, Packer JE, Slater TF et al. Reaction of the trichloromethyl radical and halothane derived peroxy radical with unsaturated fatty acids: a pulse radiolysis study. Chem Boil Interact. 1983; 85:171-177.

[29]. [29]. Tribble DL, Aw TY, Jones DP. The pathophysiological significance of lipid peroxidation in oxidative cell injury. Hepatology. 1987; 7:377-386.

[30]. Wang PY, Kaneko T, Tsukada $\mathrm{H}$ et al. Time courses of hepatic injuries induced by chloroform and by carbon tetrachloride: comparison of biochemical and histopathological changes. Arch Toxicol. 1997; 71(10):638-645.

[31]. Park WH, Lee SK, Kim CH. A Korean herbal medicine, panaxnotoginseng, prevents liver fibrosis and hepatic microvascular dysfunction in rats. Life Sci. 2005; 76:1675-1690. 
[32]. Mehmetcik G, Ozdemirler G, Koc N et al. Role of carnosine in preventing thioacetamide-induced liver injury in the rat. Peptides. 2008; 29:425-429.

[33]. Vigila AG, Baskaran X. Immunomodulatory effect of coconut protein on cyclophosphamide induced immune suppressed Swiss Albino mice. Ethnobot Leaflets 2008; 12: 1206-1212.

[34]. ManishaDebMandal, ShyamapadaMandal. Coconut (Cocosnucifera L.: Arecaceae): In health promotion and disease prevention. Asian Pacific Journal of Tropical Medicine. 2011; 241-247.

[35]. Smuckler EA, Iseri OA, Benditt EP. An intracellular defect in protein synthesis induced by carbon tetrachloride. J Exp Med. 1962; 116: $55-72$.

[36]. Recknagel RO, Glende JEA, Dolack JA et al. Mechanisms of carbon tetrachloride toxicity. PharmacolTher. 1989; 43:139-154

[37]. Ko KM, Ip SP, Poon MK, Wu SS,Che CT, Ng KH, Kong YC. Effect of A Lignin-Enriched FructusSchisandrae Extract on Hepatic Glutathione Status in Rats: Protection Against Carbon Tetrachloride Toxicity, Planta Med. 1995; 61: $134-137$.

[38]. Quan J, Yin X, Xu H. Boschniakiarossica prevents the carbon tetrachloride-induced hepatotoxicity in rat. ExpToxicolPathol.2009; Epub ahead of print.

[39]. Aricı OF, Cetin N (2011) Protective role of ghrelin against carbon tetrachloride (CCl4) induced coagulation disturbances in rats. RegulPept.166:139-142.

[40]. Sepaniak S, Forges T, Gerard H, Foliguet B, Bene MC,Monnier-BarbarinoP. The Influence of Cigarette Smoking on Human Sperm Quality and DNA Fragmentation. Toxicology. 2006; 223 54-60.

[41]. Nair SVG and Rajamohan T. The Role of Coconut Water on Nicotine-Induced Reproductive Dysfunction in Experimental Male Rat Model. Food and Nutrition Sciences. 2014; 5 1121-1130. 